University of Nebraska - Lincoln

DigitalCommons@University of Nebraska - Lincoln

Transactions of the Nebraska Academy of

Sciences and Affiliated Societies

Nebraska Academy of Sciences

$7-24-2020$

\title{
Ornate Box Turtles (Terrapene ornata) copulating in water: an incidental observation or ancestral behavior
}

\author{
Ashley Forrester \\ Univeristy of Nebraska at Kearney, forresteraj@lopers.unk.edu \\ Michael Rohde \\ Univeristy of Nebraska at Kearney, rohdeml@lopers.unk.edu \\ Mary Harner \\ Univeristy of Nebraska at Kearney, harnermj@unk.edu \\ Carter Kruse \\ Turner Enterprises, Inc., carter.kruse@retranches.com \\ Keith Geluso \\ University of Nebraska-Kearney, gelusok1@unk.edu
}

Follow this and additional works at: https://digitalcommons.unl.edu/tnas

Part of the Biology Commons

Forrester, Ashley; Rohde, Michael; Harner, Mary; Kruse, Carter; and Geluso, Keith, "Ornate Box Turtles (Terrapene ornata) copulating in water: an incidental observation or ancestral behavior" (2020).

Transactions of the Nebraska Academy of Sciences and Affiliated Societies. 524.

https://digitalcommons.unl.edu/tnas/524

This Article is brought to you for free and open access by the Nebraska Academy of Sciences at DigitalCommons@University of Nebraska - Lincoln. It has been accepted for inclusion in Transactions of the Nebraska Academy of Sciences and Affiliated Societies by an authorized administrator of DigitalCommons@University of Nebraska - Lincoln. 


\title{
Ornate Box Turtles (Terrapene ornata) copulating in water: an incidental observation or ancestral behavior
}

\author{
Ashley J. Forrester, ${ }^{1}$ Michael L. Rohde, ${ }^{1}$ Mary J. Harner, ${ }^{1,2}$ Carter Kruse, ${ }^{3}$ and Keith Geluso, ${ }^{*, 1}$ \\ 1 Department of Biology, University of Nebraska at Kearney, Kearney, Nebraska, 68849 USA \\ 2 Department of Communication, University of Nebraska at Kearney, Kearney, Nebraska, 68849 USA \\ 3 Turner Enterprises, Inc., Bozeman, Montana, 59718 USA \\ *Corresponding author: Keith Geluso; 308-865-8982; email gelusok1@unk.edu
}

\begin{abstract}
Herein, we report the first observation of the terrestrial Ornate Box Turtle (Terrapene ornata) copulating in water. To understand whether such an event reflected an isolated incident, we compiled observations reported in the literature of copulatory behaviors in water for other North American turtles. Our literature review revealed that other species of box turtles in North America, the Coahuilan Box Turtle (Terrapene coahuila) and Gulf Coast Box Turtle (Terrapene carolina major), occasionally also copulate in water. The vast majority of turtles in North America copulate in water, as most are semi-aquatic, including all species with observations in the Emydidae family. We did not find observations for water copulations in tortoises (Testudinidae), the most terrestrial group of turtles in North America. Although Ornate Box Turtles are terrestrially adapted, box turtles are within the family Emydidae, the pond turtles. Copulation in this fluid medium for terrestrial species might aid in the reproductive process with increased buoyancy and stability counteracting the high dome-shaped carapace that likely hinders copulation on land. Such a behavior also might help conceal individuals from predators or conspecific males that might disrupt copulating individuals. If ponded water is available within habitats for these terrestrially adapted box turtles, we predict underwater copulatory behaviors might be more common than recognized and remain undetected due to the inconspicuous nature of locations and rarity of ponded water in such habitats.
\end{abstract}

Keywords: copulation, Nebraska, Ornate Box Turtle, Sandhill Region, Terrapene ornata

DOI: $10.32873 /$ unl.dc.tnas. 40.3

The Ornate Box Turtle (Terrapene ornata) is a terrestrial species, adapted to living in semiarid grasslands, prairies, and sand dunes of the central and southern Great Plains, as well as in arid habitats of the southwestern United States and wooded and prairie habitats in the Midwest (Legler 1960, Ernst and Lovich 2009). With a high-arched carapace, flattened forelimbs for digging, and widened, thickened toes, appearances and habitats of Ornate Box Turtles are likened to that of tortoises (Legler 1960, Ernst and Lovich 2009, Orenstein 2012). Although superficially similar to tortoises, Ornate Box Turtles are in the pond turtle family, Emydidae, and available water is important for this terrestrial species (Clarke 1950, Blair 1976, Ernst and Lovich 2009).

Ornate Box Turtles commonly use wetland habitats when they occur in their environments. Wetland margins are used for drinking (Blair 1976, Ernst and Lovich 2009).
Water also can help conceal turtles, as Clarke (1950) observed a male and two female ornate box turtles partially submerged in shallow water on two separate occasions. When approached, females became fully submerged, with only the top of carapaces visible. Blair (1976) and Legler (1960) also observed multiple individuals resting partially or fully submerged in water between May and August. Use of aquatic habitats was most common by gravid females in May, and common for males and females during the hottest periods of July (Converse and Savidge 2003), as edges of water bodies are used for thermoregulation when summer ambient temperatures are high (Ernst and Lovich 2009). Thus, such aquatic behaviors can be used for concealment and thermoregulation.

Ornate Box Turtles are surprisingly agile in water (Norris and Zweifel 1950). Ernst and Lovich (2009) considered this species to be relatively good swimmers, as 
T. ornata has been observed swimming in and across bodies of water numerous times (e.g., ponds and rivers; Clarke 1950, Norris and Zweifel 1950). Despite multiple observations of T. ornata in aquatic habitats (Clarke 1950, Blair 1976, Dodd 2002, Converse and Savidge 2003, Ernst and Lovich 2009), we did not locate published observations of this species mating in water. The species has been documented copulating on land (Brumwell 1940, Legler 1960). Herein, we describe the first observation of copulation for T. ornata in water. We also compiled other observations of turtles copulating in water across North America to better understand whether such an event reflected an incidental occurrence. Lastly, we discuss possible benefits of this behavior for a terrestrial turtle species.

On 12 July 2019, we observed a male and female $T$. ornata copulating in a small lake $(525 \mathrm{~m} \times 420 \mathrm{~m})$ in the Sandhill Region of Nebraska $(26.6 \mathrm{~km} \mathrm{~S}$ and $18.5 \mathrm{~km} \mathrm{~W}$ Gordon, Fawn Lake Ranch, Cherry County; $42.48577^{\circ} \mathrm{N}$, $101.88816^{\circ} \mathrm{W}$; WGS 84). The two individuals were observed in water about $7 \mathrm{~cm}$ deep and about $30 \mathrm{~cm}$ from the shoreline. Aquatic vegetation at the location consisted mainly of duckweed (Lemna). At the water's edge, vegetation consisted of a small patch of sand cherry (Prunus), prairie cordgrass (Spartina pectinata), and bulrush (Scirpus) flattened by recent hail storms (botanical names follow Kaul et al. 2011). When approached, the male was partially submerged with its head and top portion of carapace above the water. Upon removal of the male from the water, we discovered a female fully submerged under water and attached to the male via the copulatory organ. Both individuals were removed from the water and placed on shore (Fig. 1). The male promptly returned into the wetland, swam, and entered an adjacent crab trap (Collapsible Crab/Fish/Crawdad Trap 32"x 24"x11", Pro$\operatorname{mar}{ }^{\circledR}$, Gardena, California). The trap was baited with sardines to survey aquatic turtles for another project. The

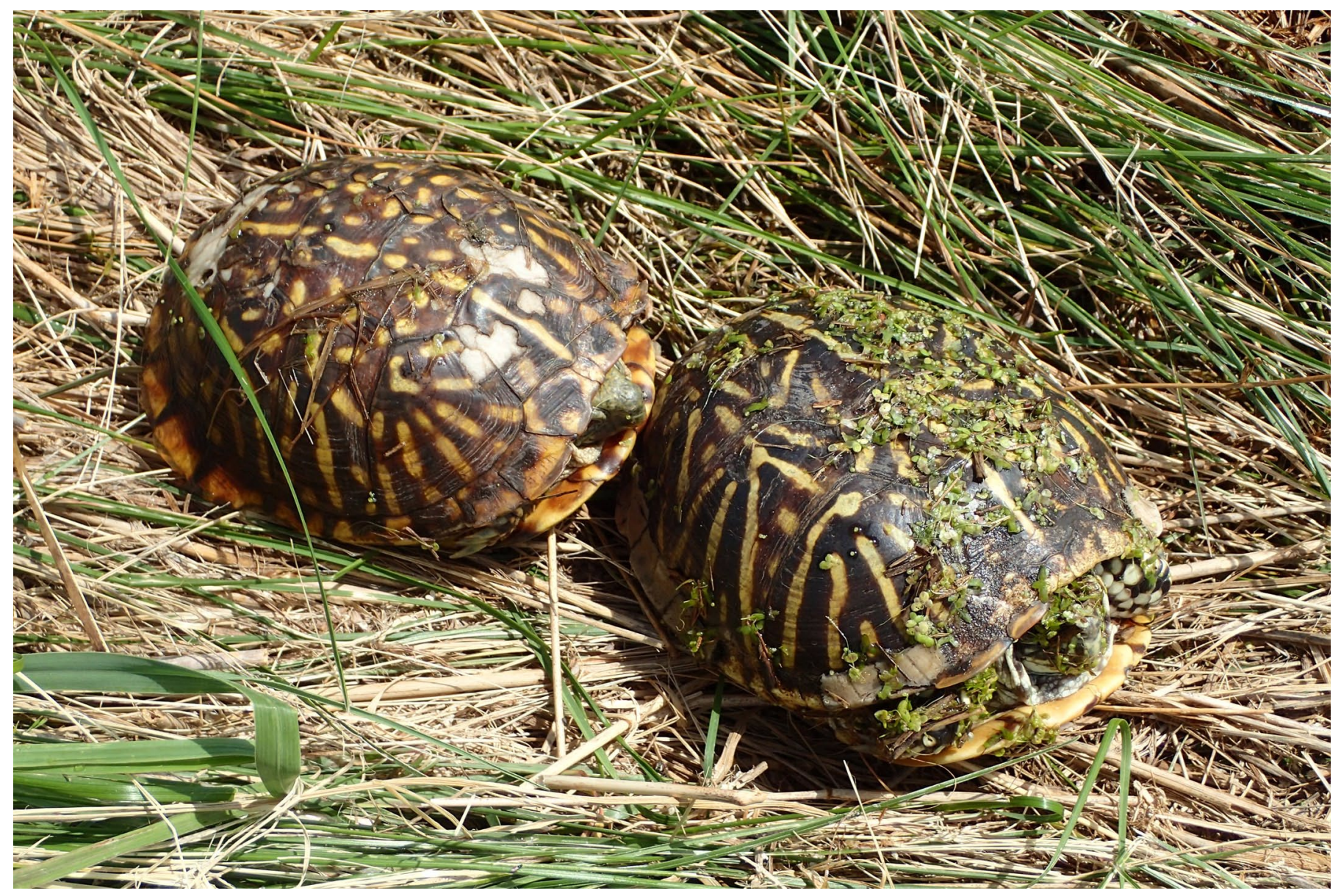

Figure 1. Male (left) and female Ornate Box Turtles (Terrapene ornata) following aquatic copulation at 10:00 h on 12 July 2019 in the Sandhills of Nebraska. The male returned to the wetland after removal from the water, but the female remained in the grassland. 
Table 1. Observations of copulatory behaviors in water for turtle species of the United States, Canada, and Mexico. See Appendix for references. Those with accounts on copulation but not in water represent those species that are only known to copulate on land.

\begin{tabular}{lccc} 
Family & Species in Family & Species with copulation location accounts & Species that copulate in water \\
\hline Cheloniidae & 5 & 5 & 5 \\
Chelydridae & 3 & 2 & 2 \\
Dermatemydidae & 1 & 1 & 1 \\
Dermochelyidae & 1 & 1 & 1 \\
Emydidae & 36 & 23 & 23 \\
Geoemydidae & 3 & 3 & 2 \\
Kinosternidae & 23 & 10 & 10 \\
Testudinidae & 4 & 4 & 0 \\
Trionychidae & 6 & 5 & 5 \\
\hline
\end{tabular}

male was removed from the trap, but he again returned to the water where we left him. The female did not return to the water during observations. We made this observation at 10:00 MDT, with an ambient air temperature of $26.6^{\circ} \mathrm{C}$ and water temperature of $23.3^{\circ} \mathrm{C}$.

Our literature review revealed that other species of box turtles in North America at least occasionally copulate in water. The Gulf Coast Box Turtle (T. carolina major) has been observed mating in shallow water multiple times (Penn and Pottharst 1940, Evans 1968, Ernst and Lovich 2009). High humidity and moderately high ambient temperatures $\left(21.1\right.$ to $26.7^{\circ} \mathrm{C}$ ) are important stimuli of copulatory behaviors for Gulf Coast Box Turtles (Penn and Pottharst 1940). For one of those observations, the humidity was low. On the other day, ambient air temperature was quite low $\left(13.3^{\circ} \mathrm{C}\right)$, but water temperatures were in the optimal range (Penn and Pottharst 1940). The Coahuilan Box Turtle (T. coahuila), an aquatic box turtle, mates primarily underwater (Brown 1974, Cerda and Waugh 1992). In general, Coahuilan Box Turtles spend most of their time in water (Brown 1974) and are considered the most aquatic American box turtle (Brown 1974, Orenstein 2012).

Observations of copulations in water for Coahuilan Box Turtles, Gulf Coast Box Turtles, and Ornate Box Turtles are consistent with behaviors for aquatic and semiaquatic turtles in North America (Ernst and Lovich 2009, Legler and Vogt 2013). The majority of turtles in Canada, Mexico, and the United States copulate in water (Table 1; Appendix). The only exceptions are tortoises, which are terrestrially adapted (Family Testudinidae; Table 1; Appendix). Within the genus Terrapene, there is some agreement that the ancestral clade is likely the aquatic Coahuilan Box Turtle (Dodd 2002), but others have hypothesized that the species descended from Eastern Box Turtles (T. carolina) (Dodd 2002, Orenstein 2012). Placement of box turtles within the semi-aquatic pond turtle family, Emydidae, suggests that our observation is potentially an ancestral behavior.

For terrestrial turtle species, copulation in water might aid in reproduction. The high-domed rounded carapaces of box turtles appear to make copulation particularly challenging with intricate positioning to copulate (Orenstein 2012). Thus, copulation in water might increase buoyancy, stability, and safety, as individuals placed in water floated high in the water with the shell never submerged (Legler 1960). Water also may provide protection from predators and aggressive competition between conspecific males. If ponded water is available within habitats for these terrestrially adapted box turtles, we predict underwater copulatory behaviors might be more common than recognized and remain undetected due to the inconspicuous nature of locations and rarity of ponded water in such habitats. Indeed, we only made such an observation because we were in walking in the shallow parts of the water body for another research project, otherwise we certainly would not have known two turtles were present and copulating. In parts of the Nebraska Sandhills, aquatic habitats are relatively common, but the landscape is largely undeveloped, which also might limit potential observations. If such a behavior is advantageous, researchers should seek additional mating observations in regions of the Sandhills where ponded water is common. Other regions throughout the distribution of this turtle might not have water during the mating season. Our literature review revealed that the location for copulation has not been described for many species of turtles. We suggest that other researchers also publish such observations. 


\section{Acknowledgments}

We thank Turner Enterprises, Inc. for providing funding, housing, and the opportunity to study turtles in the Nebraska Sandhills. We thank Prairie Biotic Research and the University of Nebraska at Kearney (UNK) Research Services Council for additional funding. The Department of Biology at UNK assisted with logistical support. We thank John Halstead for field and logistical support. We thank the anonymous reviewers for comments on an early version of this manuscript. Our opportunistic observation of aquatic copulation for the Ornate Box Turtle occurred while conducting research on Blanding's Turtles (Emydoidea blandingii) on Fawn Lake Ranch.

\section{Literature Cited}

Blair WF. (1976) Some aspects of the biology of the Ornate Box Turtle, Terrapene ornata. The Southwestern Naturalist 21: 89-103.

Brown WS. (1974) Ecology of the Aquatic Box Turtle, Terrapene coahuila (Chelonia, Emydidae) in northern Mexico. Bulletin of the Florida State Museum, Biological Sciences 19: 1-67.

Brumwell MJ. (1940) Notes on the courtship of the turtle, Terrapene ornata. Transactions of the Kansas Academy of Science 43: 391-392.

Cerda A and Waugh D. (1992) Status and management of the Mexican Box Terrapin Terrapene coahuila at the Jersey Wildlife Preservation Trust. Dodo, Journal of the Jersey Wildlife Preservation Trust 28: 126-142.

Clarke RF. (1950) Notes on the Ornate Box Turtle. Herpetologica 6: 54 .

Converse SJ and Savidge JA. (2003) Ambient temperature, activity, and microhabitat use by Ornate Box Turtles (Terrapene ornata ornata). Journal of Herpetology 37: 665-670.

Dodd Jr CK. (2002) North American box turtles: a natural history (Norman, Oklahoma: University of Oklahoma Press).
Ernst CH and Lovich JE. (2009) Turtles of the United States and Canada. $2^{\text {nd }}$ Edition (Baltimore, Maryland: John Hopkins University Press).

Evans LT. (1968) The evolution of courtship in the turtle species, Terrapene carolina. American Zoologist 8: 695-696.

Kaul RB, Sutherland D, and Rolfsmeier S. (2011) The flora of Nebraska. $2^{\text {nd }}$ Edition (Lincoln, Nebraska: School of Natural Resources, University of Nebraska-Lincoln).

Lardie RL. (1975) Courtship and mating behavior in the Yellow Mud Turtle Kinosternon flavescens flavescens. Journal of Herpetology 9: 223-227.

Legler JM. (1960) Natural history of the Ornate Box Turtle, Terrapene ornata ornata Agassiz. University of Kansas Publications, Museum of Natural History 11: 531-669.

Legler JM and Vogt RC. (2013) The turtles of Mexico: land and freshwater forms (Berkeley, California: University of California Press).

Norris KS and Zweifel RG. (1950) Observations on the habits of the Ornate Box Turtle, Terrapene ornata (Agassiz). Natural History Miscellanea 58: 1-4.

Orenstein RI. (2012) Turtles, tortoises, and terrapins: a natural history. $2^{\text {nd }}$ Edition (Richmond Hill, Ontario, Canada: Firefly Books Ltd.).

Penn Jr GH and Pottharst KE. (1940) The reproduction and dormancy of Terrapene major in New Orleans. Herpetologica 2: 25-29.

Smith PW and Hensley MM. (1957) The Mud Turtle, Kinostern flavescens stejnegeri hartweg, in the United States. Proceedings of the Biological Society of Washington 70: 201-204.

Wahlquist H. (1970) Sawbacks of the Gulf Coast. International Turtle and Tortoise Society Journal 4: 10-28. 


\section{APPENDIX}

Turtle species of North America with documented copulation locations in water, including citations of where data were obtained. Numbers in parentheses after familial names represent the total number of species known from North America.

Chelonidae (5): Caretta caretta (Ernst and Lovich 2009), Chelonia mydas (Ernst and Lovich 2009), Eretmochelys imbricata (Ernst and Lovich 2009), Lepidochelys kempii (Ernst and Lovich 2009), Lepidochelys olivacea (Ernst and Lovich 2009).

Chelydridae (3): Chelydra serpentina (Ernst and Lovich 2009), Macrochelys temminckii (Ernst and Lovich 2009).

Dermatemydidae (1): Dermatemys mawi (Legler and Vogt 2013).

Dermochelyidae (1): Dermochelys coriacea (Ernst and Lovich 2009).

Emydidae (36): Actinemys marmorata (Ernst and Lovich 2009), Chrysemys picta (Ernst and Lovich 2009, Legler and Vogt 2013), Clemmys guttata (Ernst and Lovich 2009), Deirochelys reticularia (Ernst and Lovich 2009), Emydoidea blandingii (Ernst and Lovich 2009), Glyptemys insculpta (Ernst and Lovich 2009), Glyptemys muhlenbergii (Ernst and Lovich 2009), Graptemys barbouri (Wahlquist 1970), Graptemys ernsti (Ernst and Lovich 2009), Graptemys geographica (Ernst and Lovich 2009), Graptemys ouachitensis (Ernst and Lovich 2009), Graptemys psuedogeographica (Ernst and Lovich 2009), Malaclemys terrapin (Ernst and Lovich 2009), Pseudemys concinna (Ernst and Lovich 2009), Pseudemys nelsoni (Ernst and Lovich 2009), Pseudemys peninsularis (Ernst and Lovich 2009), Pseudemys suwanniensis (Ernst and Lovich 2009), Pseudemys texana (Ernst and Lovich 2009), Terrapene carolina (Ernst and Lovich 2009), Terrapene coahuila (Legler and Vogt 2013), Terrapene ornata (this study), Trachemys gaigeae (Ernst and Lovich 2009), Trachemys scripta (Ernst and Lovich 2009, Legler and Vogt 2013).

Geoemydidae (3): Rhinoclemmys areolata (Legler and Vogt 2013), Rhinoclemmys pulcherrima (Legler and Vogt 2013).

Kinosternidae (23): Kinosternon arizonense (Smith and Hensley 1957), Kinosternon baurii (Lardie 1975), Kinosternon flavescens (Ernst and Lovich 2009, Legler and Vogt 2013), Kinosternon herrerai (Legler and Vogt 2013), Kinosternon leucostomum (Legler and Vogt 2013), Kinosternon sonoriense (Ernst and Lovich 2009, Legler and Vogt 2013), Kinosternon subrubrum (Ernst and Lovich 2009), Sternotherus carinatus (Ernst and Lovich 2009), Sternotherus minor (Ernst and Lovich 2009), Sternotherus odoratus (Ernst and Lovich 2009).

Trionychidae (6): Apalone atra (Legler and Vogt 2013), Apalone mutica (Ernst and Lovich 2009), Apalone spinifera (Ernst and Lovich 2009), Palea steindachneri (Ernst and Lovich 2009), Pelodiscus sinensis (Ernst and Lovich 2009). 